\title{
KESIAPAN DIREKTORAT JENDERAL PAJAK (DJP) DALAM PEMUNGUTAN PAJAK DIGITAL BERDASARKAN FAKTOR INDIVIDUAL
}

\section{Radithia, Inayati}

Ilmu Administrasi Universitas Indonesia (UI) Depok Jawa Barat, Indonesia

Email: radithiaanwar@gmail.com, inayati.hifni01@gmail.com

\begin{abstract}
Abstrak
Perkembangan teknologi informasi dan komunikasi telah meningkatkan jumlah pengguna internet di berbagai dunia, sehingga smartphone dan layanan data internet menjadi sebuah kebutuhan di era modern ini. Perubahan perilaku masyarakat telah menciptakan fenomena berbelanja secara online dan berkembangnya industri ecommerce secara masif. Di Indonesia sendiri tercatat ada sekitar 4.5 juta penjual online yang aktif berdagang di tahun 2017 dengan proyeksi nilai penjualan barang kotor sebesar 55-65 milyar USD di tahun 2022. Potensi besar dari industri ecommerce ini dibersamai dengan tantangan bagi Direktorat Jenderal Pajak (DJP) untuk melakukan pemajakan terhadap para pelaku bisnis yang terlibat dalam Perdagangan Melalui Sistem Elektronik (PMSE). Berdasarkan latar belakang tersebut, penelitian ini dilakukan dengan tujuan untuk melakukan analisa terkait kesiapan DJP dalam melakukan pemungutan pajak digital di Indonesia yang ditinjau dari dimensi faktor individual. Dengan menggunakan pendekatan postpositivisme dengan menggunakan metode kualitatif dalam melakukan analisia penelitian. Penelitian ini menemukan bahwa aparatur pajak di kantor pusat DJP telah menyadari akan adanya perubahan lingkungan bisnis yang mengarah pada digitalisasi dan menilai perlu adanya perubahan dari sisi organisasi DJP. Dan kesimpulan dari penelitian ini adalah DJP telah memiliki kesiapan dari Faktor Individual.
\end{abstract}

Kata Kunci: kesiapan organisasi; kebijakan pajak; pajak digital; ekonomi digital

\section{Abstract}

The development of information and communications technology has increased the number of internet users in the world, so that smartphones and internet data services have become a necessity in this modern era. Changes in people's behavior have created the phenomenon of online shopping and the massive development of the e-commerce industry. In Indonesia, there are around 4.5 million online sellers who are actively trading in 2017 with a projected gross merchandise value of 55-65 billion USD in 2022. The huge potential of the e-commerce industry is in line with the challenges to collect the tax from the actors involved in trading through an electronic system (PMSE) by the Directorate General of Taxes (DGT). Based on this background, this research was conducted to analyze the DGT's readiness to collect digital tax in Indonesia in terms of the dimensions of Individual Factors. This study uses a post-positivism approach with qualitative method in conducting research analysis. Based on the analysis that has been carried out, this study found

$\begin{array}{ll}\text { How to cite: } & \text { Radhitia \& Inayati (2021) Kesiapan DJP Dalam Pemungutan Pajak Digital Berdasarkan Faktor Individual. } \\ & \text { Syntax Literate: Jurnal Ilmiah Indonesia, 6(12). http://dx.doi.org/10.36418/Syntax-Literate.v6i12.5051 } \\ \text { E-ISSN: } & \text { 2548-1398 } \\ \text { Published by: } & \text { Ridwan Institute }\end{array}$


that the tax officials at the DGT head office are aware of changes in the business environment that have led to the digitization and assess that there is a need for changes in the DGT organization. And this research concludes that DGT has readiness from Individual Factors in conducting digital tax collection in Indonesia.

Keywords: organizational readiness; tax policy; digital tax; digital economy

Received: 2021-11-20; Accepted: 2021-12-05; Published: 2021-12-20

\section{Pendahuluan}

Perkembangan teknologi informasi dan komunikasi pada saat ini telah berpengaruh sangat besar dalam perkembangan dunia. Internet adalah salah satu turunan dari perkembangan teknologi informasi dan komunikasi yang telah banyak merubah gaya hidup dan kebiasaan masyarakat luas. Berinteraksi dengan teman, kolega atau keluarga saat ini sudah tidak lagi dibatasi oleh ruang dan waktu. Internet telah memperkenalkan kepada dunia cara baru untuk berkomunikasi, mempermudah dalam mengelola suatu informasi dan membagikan informasi secara cepat dan global.

Hal ini menarik mengingat enam dekade lalu internet bukanlah sesuatu yang umum dan tidak dapat digunakan oleh masyarakat luas. Tepatnya pada tahun 1957 lembaga ARPA (Advanced Research Projects Agency) di Amerika Serikat menemukan sebuah bentuk awal dari cikal bakal internet saat ini yang disebut dengan ARPANet yang tujuannya pada saat itu diciptakan ARPANet adalah untuk keperluan pemerintah dan militer. Dan secara kontekstual dapat diartikan bahwa internet mengacu pada sistem informasi global yang memiliki tiga karakteristik, yaitu (i) terhubung secara global; (ii) dapat mendukung komunikasi dan; (iii) layanannya dapat diakses secara publik ataupun pribadi dengan infrastruktur terkait (Bardopoulos, 2015).

Internet saat ini yang mendapat julukan sebagai "the virtual world" telah berhasil menciptakan beberapa Mega Cyber Corporations yang saat ini menjadi world market leader. Amazon.com dinyatakan sebagai "the founding father of the virtual marketplace" karena dianggap telah memperkenalkan cara baru dalam berbisnis, yaitu dengan metode Online yang memanfaatkan jejaring internet. Sejak hadirnya Amazon.com maka mulai diperkenalkanlah era E-Commerce yang implikasinya pada modern ini menjadi suatu anomali di dunia. Namun tidak hanya Amazon.com yang satu-satunya perusahaan yang bergerak di dunia virtual melainkan ada beberapa perusahaan raksasa lainnya yang beroperasi dalam dunia virtual seperti (Bardopoulos, 2015):

- Microsoft - penyedia informasi teknologi utama;

- Google - perusahaan multinasional yang beromzet multibillion-dollar;

- eBay - role model dalam platform virtual marketplace;

- PayPal - fasilitator perbankan dan penyimpanan keuangan dunia maya yang menawarkan lebih dari 100 juta akun secara global;

- $\quad$ iTunes - penyedia layanan musik dan media yang dapat diunduh dari dunia virtual. 
Hal ini terjadi karena kemajuan teknologi dan meningkatnya jumlah pengguna internet di berbagai negara, membuat smartphone dan layanan data internet menjadi barang wajib yang harus dimiliki setiap orang. Di era modern ini konsumen lebih memilih berbelanja dari jarak jauh atau secara online daripada harus datang langsung ke toko. Fenomena kebangkitan e-commerce telah menghilangkan batasan yang ada dan menjadikan dunia lebih dekat satu sama lain, e-commerce telah tumbuh menjadi salah satu industri yang pertumbuhannya paling cepat dan paling menjanjikan saat ini. Perkembangan industri e-commerce tidak terbatas oleh demografis apapun, baik itu usia, jenis kelamin, lokasi, dan lainnya. Pengalaman berbelanja yang menyenangkan ditawarkan oleh platform e-commerce, pelanggan dimanjakan dengan pilihan produk dan merek yang beragam dengan harga yang lebih kompetitif dibanding di toko tradisional (Mathur, 2019).

Dan apabila berbicara mengenai seberapa besar ketertarikan masyarakat dunia dengan e-commerce dalam beberapa dekade terakhir ini, mengutip data dari Google Trends (Gambar 1) dari kurun waktu 10 tahun yaitu 2009 hingga September 2019 terlihat ketertarikan warganet akan $e$-commerce terus meningkat secara bertahap.

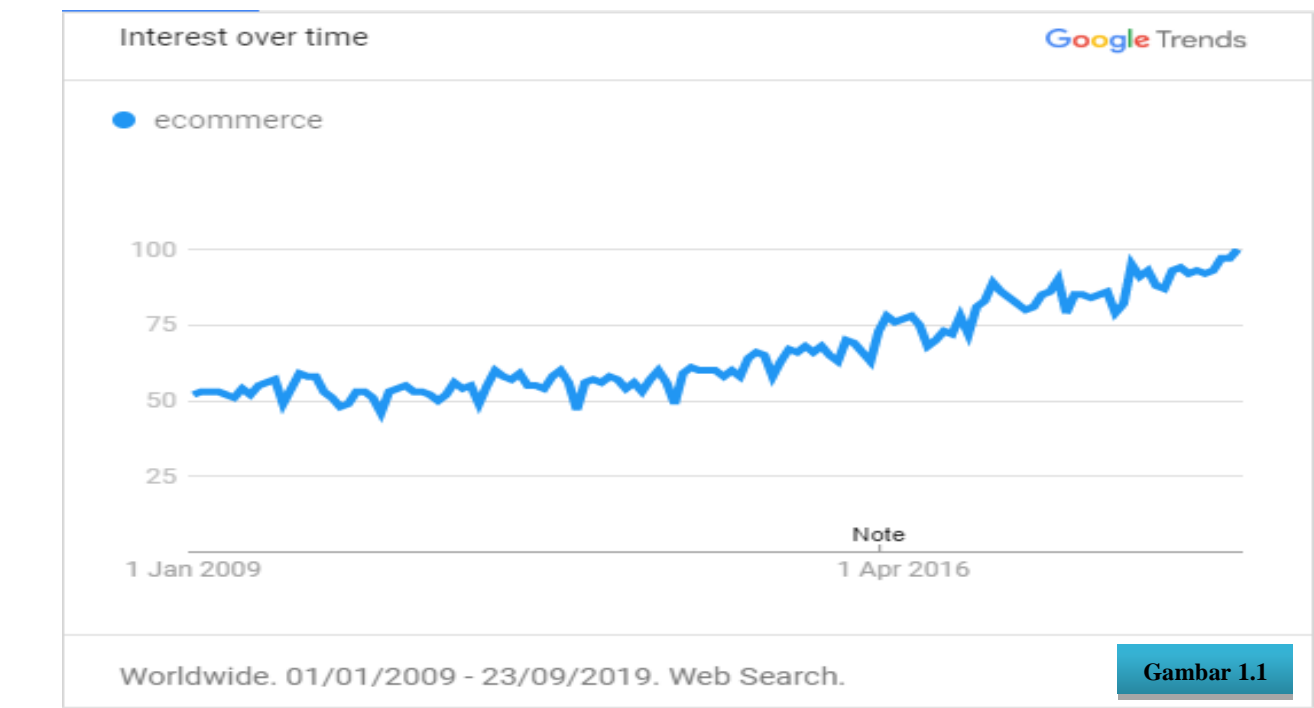

\section{Gambar 1 \\ Data trend ketertarikan ecommerce di dunia dari 01/01/2009 - 23/09/2019 dalam situs pencarian Google}

Sumber: Google Trends (dikutip tanggal 25 September 2019)

Beralih kepada fenomena berkembangnya e-commerce di Indonesia dan membandingkannya dengan negara maju seperti China, Amerika Serikat dan Singapura memang Indonesia masih terlihat relatif kecil jumlah kontribusi dari e-marketplace pada khususnya terhadap GDP (Gross Domestic Product) Indonesia seperti yang terlihat pada gambar 2 dibawah. Namun apabila membandingkannya dengan sesama negara berkembang seperti Thailand, Malaysia dan Vietnam justru Indonesia berada diatas negara-negara tersebut bersama dengan India. Dan yang terpenting adalah dari sisi 
pertumbuhan e-commerce, Indonesia mampu melebihi negara-negara maju, yaitu dengan persentase 50\% kenaikannya di 2017 dibanding dengan tahun sebelumnya seperti yang terlihat pada gambar 2 .
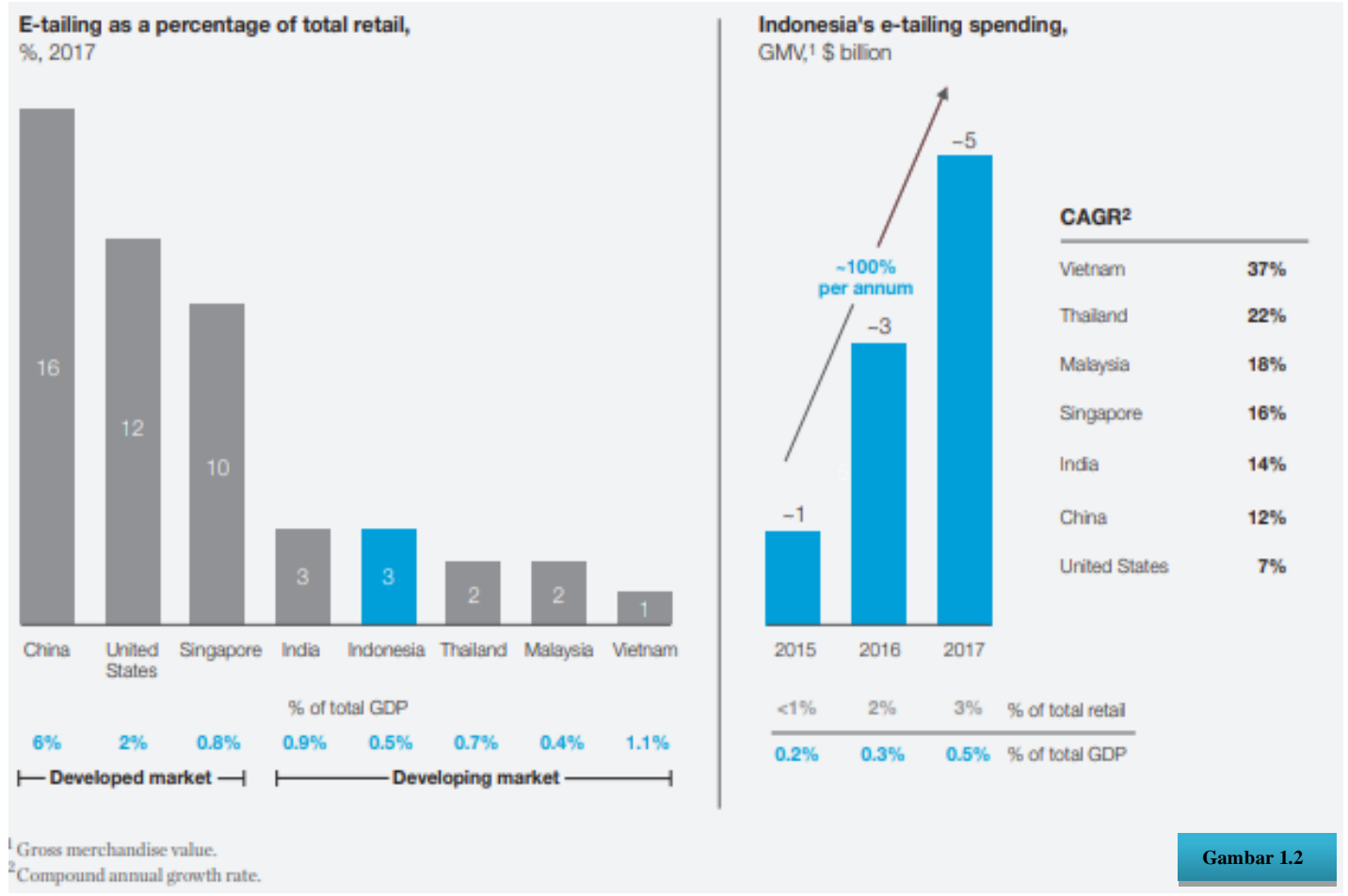

\section{Gambar 2}

Data pertumbuhan dan kontribusi e-tailing/e-marketplace tahun 2017

Sumber: (Das et al., 2018)

Dengan adanya fakta bahwa potensi pasar dari e-commerce di Indonesia yang cukup tinggi, hal ini membuat banyak investor yang datang untuk mendanai perusahaan-perusahaan rintisan atau Startup asal Indonesia yang bergerak di bidang $e$ commerce ini. Tercatat sekitar 5 milyar US dollar investasi yang telah masuk ke pasar Indonesia dan nominal ini setara dengan 38\% dari keseluruhan total investasi di perusahaan berbasis internet yang dibuat di Asia Tenggara dari tahun 2015 hingga 2017 (Das et al., 2018). Oleh karena itu pertumbuhan industri e-commerce diproyeksikan akan terus bertumbuh dan menyumbang kontribusi yang positif terhadap GDP Indonesia di masa mendatang. Di mana pada tahun 2022 diproyeksikan penjualan barang dagang melalui e-commerce dapat mencapai sekitar 55 - 65 milyar US dollar, yakni 15-25 milyar dalam platform social commerce dan 40 milyar dalam platform e-tailing/emarketplace (Das et al., 2018).

Pertumbuhan industri e-commerce yang sangat masif ini merupakan hasil turunan dari perkembangan berkelanjutan teknologi internet di dunia yang berampak dinamis pada perdagangan dan juga perpajakan. Anomali ini telah mendorong evaluasi lebih lanjut secara simultan terhadap sistem perpajakan di Indonesia bahkan dunia. Adaptasi 
perpajakan sangat memegang peranan penting bagi Direktorat Jenderal Pajak (DJP) untuk dapat mengamankan kas negara. Karena permintaan atas pasar ekonomi digital di Indonesia terus bertumbuh besar dan memberikan potensi yang sangat besar pula terhadap penerimaan pajak dari sektor bisnis berbasis internet. Namun potensi yang besar tersebut juga dibersamai dengan tantangan bagi pemerinah dalam melakukan pemajakan terhadap para pelaku bisnis tersebut, baik dari dalam maupun luar negeri. Karakteristik dari ekonomi digital merupakan suatu permasalahan bagi DJP karena skema atau alur transaksinya yang cukup variatif.

\section{Metode Penelitian}

Penelitian ini menggunakan pendekatan post-positivisme (postpositivism), dengan menggunakan metode kualitatif. Pendekatan post-positivisme memegang filosofi determinisme, bahwa suatu peristiwa tertentu adalah merupakan konsekuensi dari kejadian sebelumnya. Dengan demikian, seorang peneliti yang menggunakan pendekatan post-positivisme akan memulai penelitian ilmiahnya dengan kerangka atau landasan teori, kemudian mengumpulkan data yang mendukung atau membantah teori, dan menganalisis data untuk mencari jawaban atas sebuah peristiwa tertentu (Creswell, 2014).

Pendekatan post-positivisme digunakan untuk mencapai sebuah pemahaman yang mendalam (insight) dan menyeluruh (whole) terhadap fenomena yang terjadi melalui proses wawancara mendalam dan observasi partisipasi dalam memahami makna fenomena yang ada tersebut serta makna simbolis dibalik realita yang ada. Lebih lanjut penelitian ini menggunakan kerangka teori 'Kesiapan Perubahan Berbasis Proses' untuk mengukur kesiapan dari organisasi (Stevens, 2013). Bermula dari proses pengumpulan data penelitian di lapangan hingga tahap analisis. Dengan demikian, pola berpikir penelitian ini ialah bersifat deduktif, di mana memulai dari pernyataan yang bersifat umum dan menarik kesimpulan yang bersifat khusus atau biasa dinamakan silogismus (Mulyadi, 2011).

Dalam penelitian ini, lokus penelitian meliputi Direktorat Peraturan Perpajakan I DJP, Direktorat Peraturan Perpajakan II DJP, Direktorat Potensi, Kepatuhan, dan Penerimaan DJP, Direktorat Data dan Informasi Perpajakan DJP, Direktorat Teknologi Informasi dan Komunikasi DJP, Direktorat Transformasi Proses Bisnis, dan Direktorat Perpajakan Internasional. Dan penelitian ini mulai dilaksanakan pada tanggal 1 Oktober 2019 hingga 31 Oktober 2020 dengan 3 (tiga) tahapan waktu. Pada bulan Oktober 2019 hingga Februari 2020 adalah proses penyusunan proposal penelitian, pada bulan Maret hingga Juni 2020 adalah tahap pengumpulan data, dan bulan Juli hingga Oktober 2020 adalah finalisasi pengumpulan data sebagian dan analisis data. Kemudian berdasarkan tujuannya, penelitian ini termasuk ke dalam jenis penelitian deskriptif. Berdasarkan dimensi waktu, penelitian ini termasuk ke dalam cross sectional. Dan Berdasarkan manfaatnya, penelitian ini termasuk sebagai penelitian murni (pure research).

Dengan menggunakan 2 (dua) sumber data, yaitu data primer dan data sekunder, penelitian ini akan menggunakan teknik pengumpulan data kualitatif melalui melalui 
wawancara mendalam, dokumentasi, dan studi kepustakaan kepada 8 orang informan. Dan untuk memastikan keabsahan data yang telah diperoleh, peneliti melakukan wawancara mendalam kepada 7 orang informan sebagai upaya triangulasi data.

\section{Hasil dan Pembahasan}

Konsepsi yang diungkapkan oleh (Stevens, 2013) memiliki perspektif bahwa Kesiapan Perubahan merupakan proses penting yang terus-menerus atau berkesinambungan sepanjang perubahan terjadi, bukan pada keadaan satu kali yang harus dicapai di awal sebelum implementasi perubahan dimulai. Fundamental dari model ini ialah mengedepankan Evaluasi Kognitif dan Afektif dari individu dalam serangkaian kondisi dan kemudian dikaitkan dengan respons yang revelan terhadap perubahan. Dan ada tiga komponen dasar dari model kesiapan perubahan berbasis proses yang digunakan sebagai dimensi utama dalam penelitian ini adalah Faktor Individual, Faktor Kolektif, dan Faktor Kontekstual. Dimensi Faktor kontekstual diturunkan lagi menjadi dua indikator, yakni indikator Kapasitas Individu dan indikator Kapasitas Organisasi. Namun, dalam penulisan artikel ini, Faktor Individiual yang akan menjadi pembahasan utama.

Secara konsep, persepsi individu terhadap perubahan merupakan salah satu poin penting dalam mengukur kesiapan sebuah organisasi. Hal fundamental dari dimensi Faktor Individual dalam penelitian ini adalah bertujuan untuk menilai persepsi dari aparatur pajak mengenai perubahan lingkungan bisnis dan keadaan organisasi saat ini. Awareness terkait adanya perubahan lingkungan bisnis dari ekonomi konvensional menjadi digitalisasi ekonomi dan sense of urgency untuk melakukan sebuah perubahan secara sistemis akan menjadi sebuah tolok ukur dalam dimensi ini. Dan berdasarkan hasil analisis yang telah dilakukan, penulis menemukan ada lima sub indikator yang menjadi pembahasan utama, yaitu terkait Proses Bisnis, Regulasi, Tata Kelola Data dan Informasi, Potensi Penerimaan Pajak, dan Keamanan Data. Kemudian, dalam setiap sub indikator tersebut juga terdapat titik kritis sebagai rincian lebih lanjut dari ringkasan hasil kajian.

Proses Bisnis, adalah sub indikator pertama dari hasil kajian penelitian ini. Berdasarkan informasi yang penulis dapat dari informan, ditemukan bahwa transformasi bisnis dan inovasi yang dinamis dari Penyelenggara Perdagangan Melalui Sistem Elektronik (PPMSE) menimbulkan asimetri informasi terhadap aparatur pajak. Hingga saat penelitian dilakukam, aparatur pajak masih memiliki persepsi bahwa proses bisnis PPMSE adalah sama dengan bisnis konvensional, kecuali sarana yang digunakan. Padahal kenyataanya adalah inovasi yang terjadi di era digitalisasi ekonomi telah membuat PPMSE melakukan banyak peningkatan atau bahkan menciptakan metode atau fitur baru dalam rangka menghasilkan pendapatan dan/atau menumbuhkan bisnisnya. Laju perubahan yang terjadi sangat cepat, berbanding terbalik dengan kemampuan dari aparatur pajak dalam mendapatkan atau setidaknya memahami informasi yang didapatnya, hal inilah yang menyebabkan aparatur pajak cenderung hanya memahami garis besar dari model bisnis PPMSE. Dan implikasi dari asimetri 
informasi dari aparatur pajak ini adalah meningkatnya potensi perselisihan dan sengketa pajak.

Regulasi, dari sisi kebijakan perpajakan, penulis menemukan bahwa sebenarnya aparatur pajak telah menyadari bahwa undang-undang perpajakan yang berlaku saat ini tidak dapat sepenuhnya melindungi penerimaan pajak negara dari distorsi sektor digital. Pertama adalah mengenai Undang-undang Nomor 42 Tahun 2009 Tentang Perubahan Ketiga Atas Undang-Undang Nomor 8 Tahun 1983 Tentang Pajak Pertambahan Nilai Barang Dan Jasa Dan Pajak Penjualan Atas Barang Mewah (UU-PPN) yang perlu dilakukan amendemen atau penambahan regulasi teknis karena perkembangan inovasi dan digitalisasi ekonomi telah membuat UU-PPN tidak lagi powerful dalam mengamankan penerimaan pajak dari PPN. Kedua adalah mengenai Undang-Undang Nomor 6 Tahun 1983 Tentang Ketentuan Umum Dan Tata Cara Perpajakan Sebagaimana Telah Beberapa Kali Diubah Terakhir Dengan Undang-Undang Republik Indonesia Nomor 16 Tahun 2009 (UU-KUP) yang sudah tidak relevan dengan era digitalisasi ekonomi yang sangat mengedepankan prinsip borderless dan merevolusi hal-hal administratif yang bersifat konvensional.

Ketiga adalah mengenai Undang-undang Nomor 36 Tahun 2008 Tentang Perubahan Keempat Atas Undang-Undang Nomor 7 Tahun 1983 Tentang Pajak Penghasilan (UU-PPh) yang tidak dapat memberikan Level-playing-field antara industri konvensional dengan industri digital yang berbasis teknologi dan antara PPMSE dalam negeri dan luar negeri. Hal ini merupakan tantangan besar bagi Indonesia bahkan dunia, karena aspeknya adalah dunia dan melibatkan yurisdiksi lain. Dan hingga saat ini UUPPh yang sudah relevan tersebut masih akan terus dipertahankan karena menunggu hasil dari konsensus global OECD. UU-KUP, UU-PPN, dan UU-PPh yang merupakan payung hukum kebijakan perpajakan di Indonesia saat ini telah usang, ketentuan teknis atau tambahan dari Kementrian Keuangan atau DJP yang diterbitkan untuk mengatasi permasalahan digitalisasi ekonomi tanpa melibatkan PPMSE atau pihak terkait lainnya akan menimbulkan penentangan dan kegaduhan. Oleh karena itu koordinasi antar lembaga pemerintah sangat dibutuhkan untuk dapat menangani permasalahan digitalisasi ekonomi, hal ini akan menciptakan kebijakan perpajakan yang lebih matang dan dapat meminimalisir tekanan publik serta potensi peningkatan compliance cost yang tidak diperlukan dari sisi Wajib Pajak (WP).

Tata Kelola Data dan Informasi, basis data adalah merupakan hal yang penting dalam era digitalisasi ekonomi. Berdasarkan hasil penelitian, penulis menemukan bahwa aparatur pajak sangat menyadari bahwa DJP masih belum memiliki cukup data terkait PPMSE, baik yang berasal dalam negeri ataupun luar negeri. Oleh karena itu, database yang terintegrasi dengan sistem utama administrasi perpajakan dan Standar Operasional Prosedur (SOP) dalam manajemen data di DJP akan sangat membantu aparatur pajak dalam melakukan tugasnya. Dan apa yang dapat dilakukan saat ini oleh aparatur pajak saat ini adalah dengan memaksimalkan penggunaan data dan informasi yang telah diterima oleh DJP tersebut sebagai acuan dalam melakukan analisis perpajakan, baik dari potensi penerimaan ataupun pengujian kepatuhan. Walaupun saat 
ini DJP juga sedang berusaha untuk menambah jumlah Instansi, Lembaga, Asosiasi, dan Pihak Lain (ILAP) untuk memperkuat basis data, terutama yang dari sektor digital.

Potensi Penerimaan Pajak, penulis menemukan bahwa aparatur pajak menyadari bahwa potensi penerimaan dari sektor digital sangat besar, tetapi realisasi penerimaan pajaknya masih kecil. Hal tersebut terjadi karena adanya perubahan perilaku masyarakat yang menjadi sangat tanggap teknologi, akses internet dan harga smartphone yang makin terjangkau telah merevolusi tatanan kehidupan masyarakat. Dan tidak dapat dipungkiri bahwa realisasi penerimaan pajak dari sektor digital masih tergolong rendah karena belum ada upaya enforcement yang cukup kuat dari DJP itu sendiri.

Keamanan Data dan Informasi, basis data yang menjadi hal terpenting dalam era digitalisasi sangat rentan akan tindak kejahatan cyber, terutama data WP yang sifatnya sangat rahasia dan dilindungi oleh negara. Oleh karena itu, upaya pengamanan basis data yang dimiliki DJP akan menjadi sangat penting kedepannya. Dan dari hasil penelitian, penulis menemukan bahwa DJP sangat menjaga komitmen terhadap perlindungan data, serta kerahasiaan data dan informasi dari WP. Tercermin dari sistem keamanan yang berlapis digunakan oleh DJP terhadap database yang dimiliki, tujuannya adalah untuk mehindari serangan hacker yang mencoba mengambil data dan informasi secara ilegal. Selain dari itu, SOP yang ditetapkan oleh DJP kepada seluruh elemen organisasi juga patut di apresiasi, seperti halnya pelarangan melakukan instalasi program tanpa izin dan penghubungan dari perangkat elektronik pribadi ke semua perangkat elektronik milik DJP, kecuali yang sudah diberikan izin.

\section{Kesimpulan}

Berdasarkan tinjauan dari dimensi Faktor Individual, penelitian ini menyimpulkan bahwa DJP telah memiliki kesiapan dalam melakukan pemungutan pajak digital di Indonesia. Kesimpulan ini diperolah dengan berlandaskan hasil penelitian bahwa pemahaman akan adanya perubahan lingkungan bisnis yang mengarah pada digitalisasi ekonomi telah disadari oleh aparatur pajak di kantor pusat DJP. Aparatur pajak memahami bahwa transformasi digital telah semakin berkembang, di mana hal ini akan berimplikasi terhadap munculnya model bisnis baru yang berbasis teknologi dan meningkatnya potensi penerimaan pajak dari sektor digital. Oleh karena itu perlu dilakukan perubahan atau penyesuaian kebijakan perpajakan yang berlaku saat ini agar dapat melindungi basis penerimaan pajak dari sektor digital, baik itu ketentuan untuk PPMSE dalam negeri ataupun PPMSE luar negeri. 


\section{BIBLIOGRAFI}

Bardopoulos, Anne Michèle. (2015). ECommerce and the Effects of Technology on Taxation: Could VAT be the eTax Solution? Google Scholar

Creswell, John W. (2014). Research Design: Qualitative, Quantitative, and Mixed Method Approach (4th ed.). Nebraska: SAGE Publications. Google Scholar

Das, Kaushik, Tamhane, Toshan, Vatterott, Ben, Wibowo, Phillia, \& Wintels, Simon. (2018). The digital archipelago: How online commerce is driving Indonesia's economic development. McKinsey \& Company, (August), 1-72. Retrieved from www.mckinsey.com/featured-insights/asia-pacific/the-digital-archipelago-howonline- Google Scholar

Google Trends. (2019). ecommerce - Explore - Google Trends. Retrieved September 23, 2019, from https://trends.google.com/trends/explore?date=2009-01-01 2019$09-23 \& \mathrm{q}=$ ecommerce

Mathur, Vipul. (2019). This Is Just The Beginning Of The E-Commerce Phenomenon. Retrieved September 23, 2019, from https://www.entrepreneur.com/article/334669

Mulyadi, Mohammad. (2011). Penelitian Kuantitatif Dan Kualitatif Serta Pemikiran Dasar Menggabungkannya. Jurnal Studi Komunikasi Dan Media, 15. Google Scholar

Republik Indonesia. Undang-Undang Nomor 6 Tahun 1983 Tentang Ketentuan Umum Dan Tata Cara Perpajakan.

Republik Indonesia. Undang-undang Nomor 36 Tahun 2008 Tentang Perubahan Keempat Atas Undang-undang Nomor 7 Tahun 1983 Tentang Pajak Penghasilan.

Republik Indonesia. Undang-undang Nomor 42 Tahun 2009 Tentang Perubahan Ketiga Atas Undang-undang Nomor 8 Tahun 1983 Tentang Pajak Pertambahan Nilai Barang Dan Jasa Dan Pajak Penjualan Atas Barang Mewah.

Stevens, Gregory W. (2013). Toward a Process-Based Approach of Conceptualizing Change Readiness. Journal of Applied Behavioral Science, 49(3), 333-360. Google Scholar

\section{Copyright holder:}

Radithia, Inayati (2021)

First publication right:

Syntax Literate: Jurnal Ilmiah Indonesia

This article is licensed under:

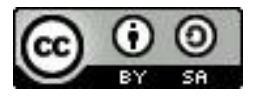

